\title{
SOSIALISASI PEMBERIAN DAUN TORBANGUN UNTUK MENINGKATKAN PRODUKSI ASI TERHADAP IBU NIFAS DI RUMAH SAKIT GRANDMED LUBUK PAKAM
}

\author{
Nadia Husna ${ }^{1 *}$, Raini Panjaitan ${ }^{1}$, Delita Br Panjaitan ${ }^{1}$, Jelita Manurung $^{1}$ \\ ${ }^{1}$ Program Studi Gizi, Institut Kesehatan Medistra Lubuk Pakam \\ JIn. Sudirman No. 38 Lubuk Pakam, Kabupaten Deli Serdang, \\ Sumatera Utara - Indonesia \\ *email korespondensi author: nadia.husna@outlook.com
}

DOI $10.35451 /$ jpk.v1i1.716

\begin{abstract}
Abstrak
Pemberian ASI eksklusif memiliki peran yang sangat besar terhadap pertumbuhan dan perkembangan pada bayi terutama pada periode 0-24 bulan. Masalah yang timbul pada ibu nifas kegagalan dalam menyusui. Salah satu penyebab kejadian kegagalan menyusui adalah kurangnya informasi pengetahuan tentang ASI dan sumber bahan pangan dapat meningkatkan produksi ASI. Pelaksanaan sosialisasi pengabdian masyarakat ini telah dilaksanakan selama tiga hari di Rumah Sakit Grandmed Lubuk Pakam. Tujuan kegiatan sosialisasi ini adalah untuk meningkatkan produksi ASI ibu nifas melalui pemberian daun torbangun. Ibu menyusui diberikan 1 porsi daun torbangun rebus selama tiga hari. Pada hari pertama tim pelaksana melakukan edukasi dan diskusi tentang manfaat daun torbangun untuk meningkatkan produksi ASI. Berdasarkan kegiatan sosialisasi ini diperoleh para peserta mendapat informasi dan pengetahuan tentang manfaat ASI dan pemanfaatan daun torbangun terhadap peningkatan produksi ASI. Dari hasil sosialisasi selama tiga hari bahwa ibu nifas dapat menyusui bayi dengan rata-rata 11,6 menit dengan lama menyusui paling lama adalah 17 menit setiap kali menyusui.
\end{abstract}

Kata kunci : Daun torbangun, air susu ibu, ibu nifas

\begin{abstract}
Exclusive breastfeeding has a very big role in the growth and development of infants, especially in the period 0-24 months. Problems that arise in postpartum mothers are failure to breastfeed. One of the causes of breastfeeding failure is the lack of information about breastfeeding and food sources that can increase breast milk production. The implementation of this community service socialization has been carried out for three days at Grandmed Lubuk Pakam Hospital. The purpose of this outreach activity is to increase breast milk production for postpartum mothers through the provision of torbangun leaves. Breastfeeding mothers were given 1 portion of boiled torbangun leaves for three days. On the first day, the implementation team conducted education and discussion about the benefits of torbangun leaves to increase breast milk production. Based on this socialization activity, participants got information and knowledge about the benefits of breastfeeding and the use of torbangun leaves to increase breast milk production. From the results of socialization for three days that postpartum mothers can
\end{abstract}


breastfeed their babies with an average of 11.6 minutes with the longest breastfeeding time is 17 minutes each time.

Keywords: torbangun leaves, breast milk, postpartum

\section{Pendahuluan}

Indonesia sangat kaya dengan sumber fitofarmaka dari jenis tanaman herba salah satunya adalah tanaman torbangun. Di Sumatera Utara tanaman torbangun atau dikenal dengan sebutan daun bangun-bangun merupakan daun yang dipercayai mampu membantu ibu menyusui setelah melahirkan. Secara empiris daun torbangun dapat meningkatkan produksi air susu ibu (ASI) dan memiliki kandungan gizi yang tinggi terutama mineral zat besi dan senyawa karoten (Hutajulu dan Junaidim 2013).

Pemberian ASI eksklusif memiliki peran yang sangat besar terhadap pertumbuhan dan perkembangan pada bayi terutama pada periode 0-24 bulan (Iwansyah dkk, 2017). Menurut (WHO, 2011), sebaiknya bayi yang baru lahir diberi air susu ibu secara eksklusif selama 6 bulan. Pemberian ASI bagi ibu menyusui tidak semua berjalan dengan mulus seperti pada ibu nifas. Ibu nifas merupakan masa pemulihan dari persalinan selesai hingga organorgan kandungan kembali seperti pra hamil selama 6-8 minggu. Pada masa nifas dapat mempengaruhi gagalnya proses menyusui pada ibu. Menurut Wendiranti dkk (2017) bahwa masalah kegagalan menyusui ASI eksklusif ibu rumah tangga yaitu ASI ibu tidak keluar di hari-hari pertama setelah melahirkan, dan beberapa ibu mengalami bahwa ASI yang keluar hanya jumlah sedikit.

Berdasarkan informasi di atas maka perlu dilaksanakan sosialisasi tentang ASI dan cara meningkatkan ASI dan mengatasi kegagalan menyusui terkhusus bagi ibu nifas. Pelaksanaan pengabdian masyarakat ini bertujuan untuk meningkatkan produksi ASI ibu menyusui melalui pemberian daun torbangun bagi ibu nifas di Rumah Sakit Grandmed Lubuk Pakam.

\section{Metode}

Metode pelaksanaan sosialisasi diawali dari pendataan jumlah pasien nifas yang sedang menyusui di Rumah Sakit Grandmed Lubuk Pakam. Selanjutnya dilakukan edukasi melalui ceramah dan diskusi tentang manfaat daun torbangun untuk meningkatkan produksi ASI. Dilakukan demonstrasi penyajian daun torbangun secara langsung beserta leaflet tentang informasi daun torbangun dan jumlah takaran agar dapat dilakukan di rumah oleh mitra kerja. Pada saat pelaksanaan kegiatan dilakukan diskusi dan tanya jawab.

\section{Hasil Dan Pembahasan}

Pelaksanaan kegiatan sosialisasi pemberian daun torbangun kepada ibu nifas di Rumah Sakit Grandmed Lubuk Pakam. Dilaksanakan pada tanggal 2628 April 2021 bertempat di Rumah Sakit Grandmed Lubuk Pakam, Jalan Raya Medan-Lubuk Pakam Km 25 No. 66 Lubuk Pakam kabupaten Deli Serdang, dengan jumlah peserta kegiatan sebanyak 15 orang ibu nifas. Pada pelaksanaan kegiatan ini dilakukan dengan penerapan protokol kesehatan.

Kegiatan ini dilaksanakan selama 3 hari. Pada hari pertama tim pelaksana melakukan penyuluhan 
Received: 04 June 2021 :: Accepted: 22 June 2021 :: Published: 30 June 2021

tentang ASI melalui ceramah dan diskusi. Adapun materi yang disampaikan adalah pengertian ASI, ASI eksklusif, karakteristik ASI, komponen ASI, manfaat ASI, jenisjenis bahan makanan pendukung produksi ASI dan pengenalan daun torbangun. Pada hari kedua dan ketiga pemberian daun torbangun. Berikut adalah karakteristik peserta kegiatan sosialisai pengabdian kepada masyarakat.

Tabel 1. Distribusi Karakteristik Peserta Sosialisasi Ibu Nifas

\begin{tabular}{lll}
\hline Karakteristik & f & \% \\
\hline a. Pekerjaan & & \\
$\quad$ Wiraswasta & 2 & 13,3 \\
Karyawan & 1 & 6,6 \\
$\quad$ Petani & 7 & 46,6 \\
$\quad$ IRT & 5 & 33,5 \\
\hline Total & $\mathbf{1 5}$ & $\mathbf{1 0 0}$ \\
\hline b. Suku & & \\
$\quad$ Batak & 3 & 20,0 \\
$\quad$ Melayu & 7 & 46,6 \\
$\quad$ Jawa & 4 & 26,8 \\
$\quad$ Nias & 1 & 6,6 \\
\hline Total & $\mathbf{1 5}$ & $\mathbf{1 0 0}$ \\
\hline
\end{tabular}

Tabel 1. Menjelaskan karakteristik peserta sosialisasi ibu nifas di Rumah Sakit Grandmed Lubuk Pakam bahwa peserta ibu nifas lebih banyak memiliki pekerjaan sebagai petani $(46,6 \%)$ serta mayoritas suku melayu sebesar $(46,6 \%)$.

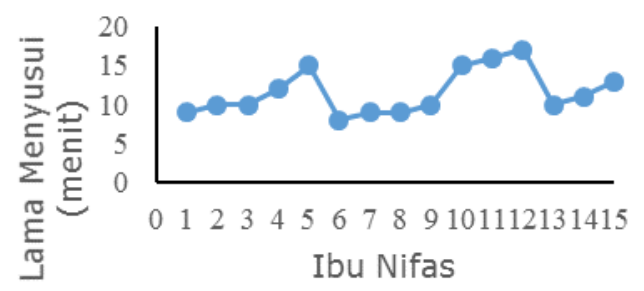

Gambar 1. Rerata Lama Menyusui (menit) Pada Ibu Nifas Selama 3 Hari

Hasil observasi lama menyusui pada 15 ibu nifas setelah pemberian daun torbangun bahwa ibu mampu menyusui dengan rata-rata selama
11,6 menit setiap kali menyusui. Berdasarkan Gambar 2. bahwa rerata ibu nifas mampu menyusui bayi setelah pemberian daun torbangun paling lama adalah 17 menit dan rerata terendah adalah 8 menit. Berdasarkan hasil observasi pada kegiatan sosialisasi bahwa rata-rata ibu dapat menyusui bayi sekitar 2-3 menit setiap kali menyusui. Menurut hasil penelitian Husna dkk (2021), bahwa sebanyak $83 \%$ ibu nifas yang mengkonsumsi daun bangun-bangun menunjukkan produksi ASI yang baik. Hal ini disebabkan bahwa ASI yang diproduksi mengandung kolostrum, protein, dan immmunoglobulin (IgA, IgG, IgM). Selain itu, adanya masa ASI transisi yaitu terjadinya perubahan pada komposisi ASI. Jumlah kolostrum, protein dan immunoglobin menurun sedangkan jumlah karbohidrat dan lemak akan meningkat (Sukma dkk, 2017). Pada sosialisasi ini menunjukkan bahwa pemberian daun torbangun mampu meningkatkan lama menyusui bagi ibu. Hal ini sesuai dengan penelitian yang telah dilakukan.

Berdasarkan hasil kegiatan pengabdian ini, bahwa pihak Rumah Rumah Sakit dan pasien ibu nifas memberikan respon yang baik. Dibuktikan dengan bahwa peserta dapat mengikuti kegiatan sosialisasi dengan baik dari awal sampai akhir kegiatan. Ibu-ibu peserta sangat antusias selama mengikuti pelatihan karena mayoritas peserta adalah sebagai ibu baru atau baru melahirkan anak pertama. Para peserta juga belum pernah menerima sosialisasi tentang pengetahuan air susu ibu (ASI) dan jenis makanan yang dapat meningkatkan produksi ASI.

Kegiatan sosialisasi merupakan upaya pengabdian kepada masyarakat yang dapat meningkatkan kemampuan dan pengetahuan cara meningkatkan 
produksi ASI bagi peserta. Salah satu langkah yang dapat dilakukan adalah pemanfaatan daun torbangun dan variasi pengolahan berbasis daun torbangun.

Daun torbangun atau daun bangun-bangun memiliki manfaat terhadap peningkatan ASI. Berdasarkan hasil penelitian yang dilakukan Hutajulu dan Junaidi (2013) secara in vitro bahwa bobot induk tikus yang diberi ekstrak daun bangunbangun mengalami peningkatan proses menyusui dan meningkatkan bobot bayi tikus. Daun torbangun memiliki fungsi sebagai laktagogum yaitu merupakan senyawa yang dapat memicu sekresi dan meningkatkan produksi ASI (Syarief dkk, 2014).

\section{Kesimpulan}

Pelaksanan kegiatan sosialisasi pemberian daun torbangun ini telah berjalan dengan baik dan sesuai dengan yang diharapkan, baik tim pelaksana, mitra kegiatan dan para peserta kegitan. Setelah mendapatkan sosialisasi para peserta mendapat informasi dan pengetahuan tentang manfaat ASI dan pemanfaatan daun torbangun terhadap peningkatan produsi ASI. Dari hasil sosialisasi selama tiga hari bahwa ibu nifas dapat menyusui bayi dengan rata-rata 11,6 menit dengan lama menyusui paling lama adalah 17 menit setiap kali menyusui.

\section{Ucapan Terima Kasih}

Penulis mengucapkan terima kasih kepada Rumah Sakit Grandmed Lubuk Pakam yang telah membantu penulis dalam kegiatan sosialisasi bagi pasien ibu nifas, beserta tim Prodi Gizi, terima kasih atas segala kerjasamanya.

\section{Daftar Pustaka}

Husna, N., Panjaitan, B, D., Febrianan, A., Ginting, Y, D., Purba, B, S.
(2021). Hubungan BangunBangun Terhadap Produksi Asi Pada Ibu Nifas Di Kelurahan Seribu Dolok. Jurnal Penelitian Kebidanan \& Kespro, 3(2), 33-39.

Hutajulu, F, T., dan Junaidi, L. (2013). Manfaat Ekstrak Daun BangunBangun (Coleus Ambonicius) Untuk Meningkatkan Produksi Air Susu Induk Tikus. Jurnal Riset Industri, 7(1),15-24.

Iwansyah., Chandra, A., dkk. (2017). potensi fraksi etil asetat daun torbangun dalam meningkatkan produksi susu, bobot badan induk dan anak tikus. jurnal gizi pangan, 12(1), 1-6

Sukma, F., Hidayati, E., \& Jamil, N. S. (2017). Asuhan Kebidanan Pada Masa Nifas. Fakultas Kedokteran dan Kesehatan, Universitas muhammadiyah Jakarta.

Syarief, H., Damanik, M, R., Sinaga, T., Doloksaribu, H, T. (2014). Pemanfaatan Daun BangunBangun Dalam Pengembangan Produk Makanan Tambahan Fungsional Untuk Ibu Menyusui. Jurnal Ilmu Pertanian Indonesia (JIPI), 19(1), 38-42.

Wendiranti, I, Catra., Subagio, W, H., \& Wijayanti, S, H. (2017). Faktor Resiko Kegagalan Asi Eksklusif. Journal Of Nutrition College, 6(3), 241-248.

World Health Organization (WHO). (2011). Exclusive breastfeeding for six Months best for babies everywhere.

https://www.who.int/mediacenter/ news/statements/2011/breastfeed ing 20110115/en/ 